\title{
DETERMINANTS OF CREDIT-LESS RECOVERIES
}

by Martin Bïsterbosch and Tatjana Dahlhaus 


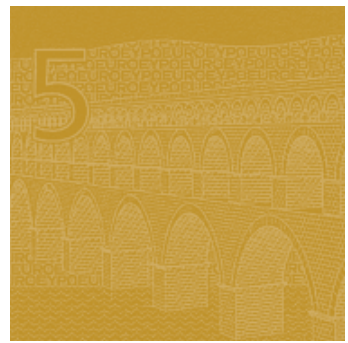

\title{
WORKING PAPER SERIES
}

NO 1358 I JUNE $20 I I$
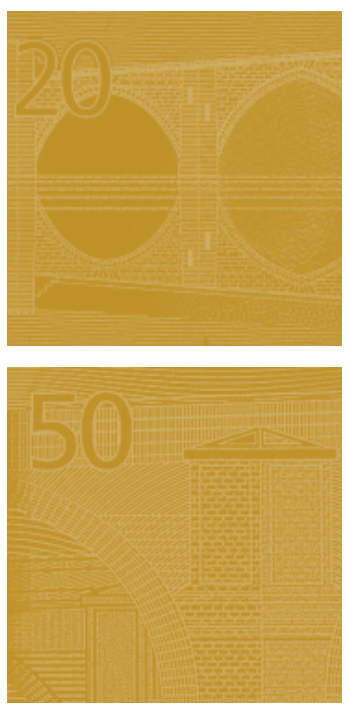

\author{
by Martin Bijsterbosch ${ }^{2}$ \\ and Tatjana Dahlhaus ${ }^{3}$
}
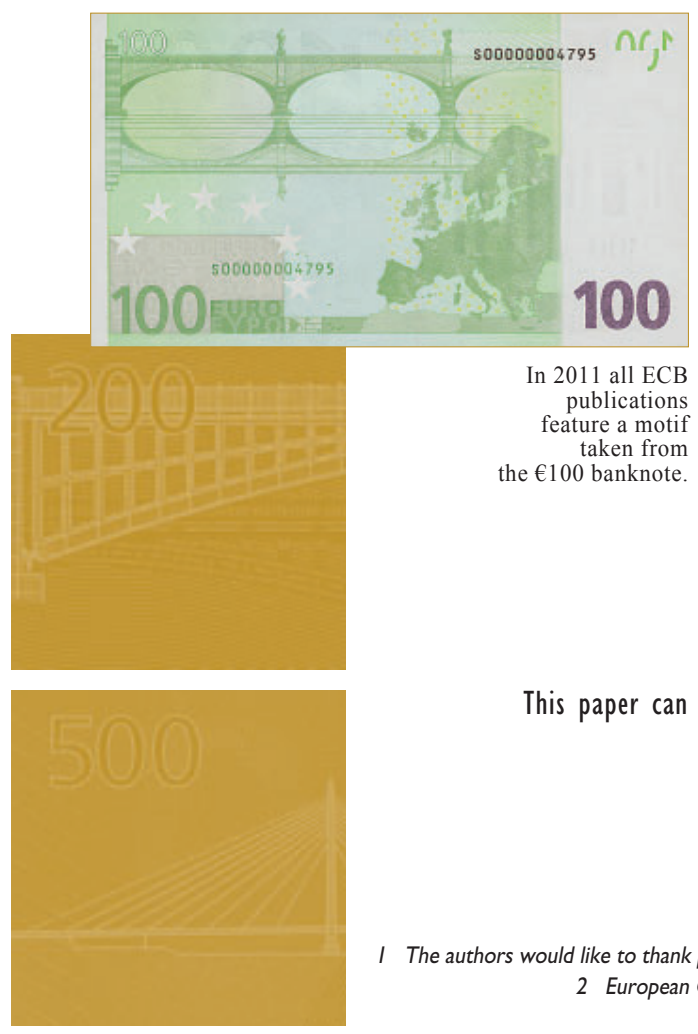

NOTE: This Working Paper should not be reported as representing the views of the European Central Bank (ECB).

The views expressed are those of the authors and do not necessarily reflect those of the ECB.

This paper can be downloaded without charge from http://www.ecb.europa.eu or from the Social Science Research Network electronic library at http://ssrn.com/abstract_id=1865215. 
(C) European Central Bank, 2011

\section{Address}

Kaiserstrasse 29

60311 Frankfurt am Main, Germany

Postal address

Postfach 160319

60066 Frankfurt am Main, Germany

Telephone

+496913440

Internet

http://www.ecb.europa.eu

Fax

+496913446000

All rights reserved.

Any reproduction, publication and reprint in the form of a different publication, whether printed or produced electronically, in whole or in part, is permitted only with the explicit written authorisation of the ECB or the authors.

Information on all of the papers published in the ECB Working Paper Series can be found on the ECB's website, http://www. ecb.europa.eu/pub/scientific/wps/date/ html/index.en.html

ISSN 1725-2806 (online) 


\section{CONTENTS}

Abstract

Non technical summary

1 Introduction

2 Data and stylised facts

2.1 Identification of credit-less recoveries

2.2 Some stylised facts

3 Determinants of credit-less recoveries

3.1 Empirical model

3.2 Explanatory variables

4 Empirical results

4.1 Main results

4.2 Marginal effects

5 Predictions

6 Conclusion

References

Figures and tables 


\begin{abstract}
This paper aims to shed light on the characteristics and particularly the determinants of credit-less recoveries. After building a dataset and documenting some stylised facts of credit-less recoveries in emerging market economies, this paper uses panel probit models to analyse key determinants of credit-less recoveries. Our main findings are the following. First, our frequency analysis confirms earlier findings that credit-less recoveries are not at all rare events. Moreover, our analysis shows that the frequency of credit-less recoveries doubles after a banking or currency crisis. Second, results from estimated panel probit models suggest that credit-less recoveries are typically preceded by large declines in economic activity and financial stress, in particular if private sector indebtedness is high and the country is reliant on foreign capital inflows. Finally, we find that the predicted probability of a credit-less recovery in central and eastern European EU Member States during the coming years varies across countries, but is relatively high in the Baltic States.
\end{abstract}

JEL classification: C23; C25; E32; E51; G01

Keywords: Credit-less Recoveries, Financial Crises, Panel Probit Models. 


\section{Non-technical summary}

During the global financial and economic crisis of 2008 and 2009, several countries in central and eastern Europe experienced drastic declines in international trade and capital flows, which were followed by large contractions in economic activity. The global financial and economic crisis had a relatively strong impact on these countries, as their preceding economic expansion had been financed by relying heavily on cross-border capital flows. Once risk aversion towards the region increased and financing conditions tightened, the region's macroeconomic imbalances made these countries highly vulnerable and required far-reaching macroeconomic adjustments. Now that these adjustment processes are coming to an end in many of these countries, the question arises what the post-crisis recovery phase could look like and what the role of credit would be in such a recovery.

This paper aims to shed light on the characteristics and particularly the determinants of credit-less recoveries, which are recoveries in output without a pick-up in credit. Such recoveries are atypical, as in "normal" recoveries output and credit growth tend to be correlated (as suggested, for example, by the theory on financial accelerators). After building a dataset and documenting some stylised facts of credit-less recoveries in emerging market economies, this paper uses panel probit models to analyse key determinants of credit-less recoveries. After estimating and comparing various panel probit models, we apply our preferred model to predict the probability of credit-less recoveries in central and eastern European EU Member States in the coming years.

Our main findings are the following. First, our frequency analysis confirms earlier findings that credit-less recoveries are not at all rare events. In our sample of low and middle income economies one out of four recoveries in output occurs without a pick-up in credit. Moreover, our analysis shows that the frequency of credit-less recoveries doubles after a banking or currency crisis. Second, panel probit models suggest that credit-less recoveries are typically preceded by large declines in economic activity and financial stress, in particular if private sector indebtedness is high and the country is reliant on foreign capital inflows. This suggests that financial frictions may indeed play a key role in the stagnation of credit despite that output recovers. Third and finally, our models suggest that (assuming that the trough in output was reached in 2009) the probability of a credit-less recovery in central and eastern European EU Member States during the coming years varies across countries, 
but is relatively high in the Baltic States.

Our findings have the following implications. They suggest that a recovery in output following a recession associated with financial stress may not be accompanied by a pick-up in lending. New credit may thus not be a necessary condition for output to recover. This does not mean, however, that credit is irrelevant for a recovery in output. Credit-less recoveries tend to be relatively weak and other related research (e.g. Kannan (2010)) shows that stressed credit conditions contribute to the sluggishness of these recoveries. To the extent that bottlenecks in the supply of credit play a role, policy measures aimed at supporting the financial intermediation process may help the recovery in output. Such policy measures should not only focus on the financial sector, but also concentrate on restoring confidence among lenders and savers. A credible fiscal consolidation strategy and structural reforms aimed at correcting the root causes of the macroeconomic imbalances built up in previous years should play a key role in this regard. Even more important are pre-emptive policies aimed at avoiding the build-up of macroeconomic imbalances. 


\section{Introduction}

During the global financial and economic crisis of 2008 and 2009, several countries in central and eastern Europe experienced drastic declines in international trade and capital flows, which were followed by large contractions in economic activity. The global financial and economic crisis had a relatively strong impact on these countries, as their preceding economic expansion had been financed by relying heavily on cross-border capital flows. Once risk aversion towards the region increased and financing conditions tightened, the region's macroeconomic imbalances made these countries highly vulnerable and required far-reaching macroeconomic adjustments. Now that these adjustment processes are coming to an end in many of these countries, the question arises what the post-crisis recovery phase could look like and what the role of credit would be in such a recovery.

A growing body of empirical and theoretical research focuses on economic recoveries after financial crises, e.g., Cerra and Saxena (2008), Kannan (2010), Abiad et al. (2011), Coricelli and Roland (2011). A stylised fact from the emerging market literature is that, after sudden stops in capital flows, output can recover with virtually no pick-up in external or domestic credit. Calvo et al. (2006a and b) were the first to document such recoveries in emerging market economies, which they characterise as Phoenix Miracles (as output "rises from its ashes" without help from credit). They find that after so-called systemic sudden stop episodes (defined as a sharp fall in capital inflows accompanied by unusually large bond spreads), output tends to return relatively quickly to pre-crisis levels, but with virtually no recovery in external or domestic credit and investment remains weak. They attribute this to the existence of financial frictions, which imply that firms can obtain short-term financing for working capital but cannot obtain long-term financing for physical capital.

In order to explain the apparent paradox of rebounding growth without credit, Biggs et al. (2009) use a (closed economy) model to show that it is the change in the flow of credit that matters for GDP growth after a financial crisis rather than the flow of credit itself. Recoveries in output can thus occur already when credit growth stops dropping, even if the rate of credit growth remains negative. Biggs et al. (2009) define a credit-less recovery as a recovery in output without a pick-up in the growth rate of credit (instead of the level of credit as defined by Calvo et al. (2006a and b) and Abiad et al. (2011)). The analysis by Biggs et al. (2009) offers additional insights into the drivers of output growth following 
financial crises, but is not inconsistent with the notion of credit-less recoveries as defined in this paper. A key point in the paper by Biggs et al. (2009) is that the link between GDP and credit is different in recovery periods characterised by financial volatility as opposed to "normal" times. During the latter, both the level and the change in credit growth matter for output growth, whereas in periods of higher financial volatility credit growth loses its significance as a driver of output growth.

Based on a comparison between credit-less and normal recoveries, Abiad et al. (2011) find that one in five recoveries is credit-less (based on a sample of advanced, emerging and lower income countries). If a systemic sudden stop is also accompanied by a banking crisis, however, the vast majority of recoveries (around 80\%) are credit-less. Moreover, Abiad et al. (2011) find that credit-less recoveries tend to be relatively weak and output growth is on average a third lower than in normal recoveries. Analysing the reasons for these differences, they conclude that impaired financial intermediation is the key factor driving these differences as recoveries without credit tend to be preceded by events that are likely to disrupt the supply of credit (such as banking crises or credit booms). This explanation is supported by their finding that industries that are more reliant on external finance seem to grow disproportionately less during credit-less recoveries (see also Kannan (2010)).

Focusing on the channels that enable the economy to recover without credit, Coricelli and Roland (2011) find that alternative sources of financing, such as trade credit, a reallocation to less credit-dependent sectors or the take-up of unused production capacity can help firms to raise their output despite tight credit conditions. Their findings show that industries that are more dependent on trade credit as opposed to bank credit recover more quickly as these industries are less vulnerable to prolonged credit market disruptions. The ability of firms to substitute trade credit for bank credit turns out to be even more important for output during credit-less recoveries, giving support to the view that credit-less recoveries are a response to disruptions in the supply of bank credit. Firm-level data confirm the importance of alternative sources of financing beyond bank credit for the ability of firms to raise their output after a financial crisis (Brown et al. (2010)).

Building in particular on Abiad et al. (2011), this paper aims to shed further light on the characteristics and especially the determinants of credit-less recoveries. More specifically, after building a dataset and documenting some stylised facts of credit-less recoveries 
in emerging market economies, this paper uses panel probit models to analyse key determinants of credit-less recoveries. To our knowledge, this is the first attempt to systematically study the determinants of credit-less recoveries using such models. After estimating and comparing various panel probit models, we apply our preferred model to predict the probability of credit-less recoveries in central and eastern European EU Member States in the coming years.

Our main findings are the following. First, our frequency analysis confirms that creditless recoveries are not at all rare events. In our sample of low and middle income economies one out of four recoveries in output occurs without a pick-up in credit. Average output growth during the first year of a credit-less recovery is a half lower than in recoveries with credit. Moreover, our analysis shows that the frequency of credit-less recoveries doubles after a banking or currency crisis. Second, our panel probit models suggest that credit-less recoveries are typically preceded by large declines in economic activity and financial stress, in particular if private sector indebtedness is high and the country is reliant on foreign capital inflows. This suggests that financial frictions may indeed play a key role in the stagnation of credit despite that output recovers. Third and finally, our models suggest that (assuming that the trough in output was reached in 2009) the probability of a creditless recovery in central and eastern European EU Member States during the coming years varies across countries, but is relatively high in the Baltic States.

Our findings have the following implications. They suggest that a recovery in output following a recession associated with financial stress may not be accompanied by a pick-up in lending. New credit may thus not be a necessary condition for output to recover. This does not mean, however, that credit is irrelevant for a recovery in output. Credit-less recoveries tend to be relatively weak and other related research (e.g. Kannan (2010)) shows that stressed credit conditions contribute to the sluggishness of these recoveries. To the extent that bottlenecks in the supply of credit play a role, policy measures aimed at supporting the financial intermediation process may help the recovery in output. Such policy measures should not only focus on the financial sector, but also concentrate on restoring confidence among lenders and savers. A credible fiscal consolidation strategy and structural reforms aimed at correcting the root causes of the macroeconomic imbalances built up in previous years should play a key role in this regard. 
Although the conclusions in this study are based on robust, empirical regularities, it needs to be borne in mind that every recovery phase has its own idiosyncratic features. In central and eastern Europe, such features may stem from the specific institutional environment associated with EU membership and the very high degree of financial integration between these countries and other EU Member States. On the one hand, tight links between international parent banks and their subsidiaries in the central and eastern European region may reduce financing constraints more than historical post-crisis recoveries in emerging markets suggest. On the other hand, such tight links could also imply a larger risk of contagion, thereby worsening financing constraints for countries in central and Eastern Europe. How these factors work out on balance depends in particular on banks' willingness and ability to maintain their exposures to the region during and in the aftermath of the global financial crisis.

This paper is structured as follows. Section 2 presents the dataset and the definition of credit-less recoveries. Moreover, some stylised facts regarding recoveries without credit are documented. Section 3 discusses the panel probit model and the explanatory variables used. Section 4 shows the empirical results obtained. In Section 5 the predictive performance of the estimated model is evaluated and predictions for central and eastern European EU Member States are presented. Section 6 concludes.

\section{Data and Stylised Facts}

\subsection{Identification of credit-less Recoveries}

As our main interest is in understanding possible recovery patterns in emerging economies in central and eastern Europe, we exclude advanced economies from our sample. The dataset consists of an unbalanced panel for 86 middle and low income countries from Latin America, Asia, Africa, central and eastern Europe and the Caribbean. The data are mainly obtained from International Financial Statistics (IFS) of the IMF. The time span ranges from 1970-2009, although data availability reduces it for many countries. To identify creditless recoveries in our sample we use real GDP (i.e., GDP divided by the GDP deflator), and real private credit (i.e., credit to the private sector divided by the GDP deflator). For these variables the minimum number of available periods for a country is 8 , the maximum 


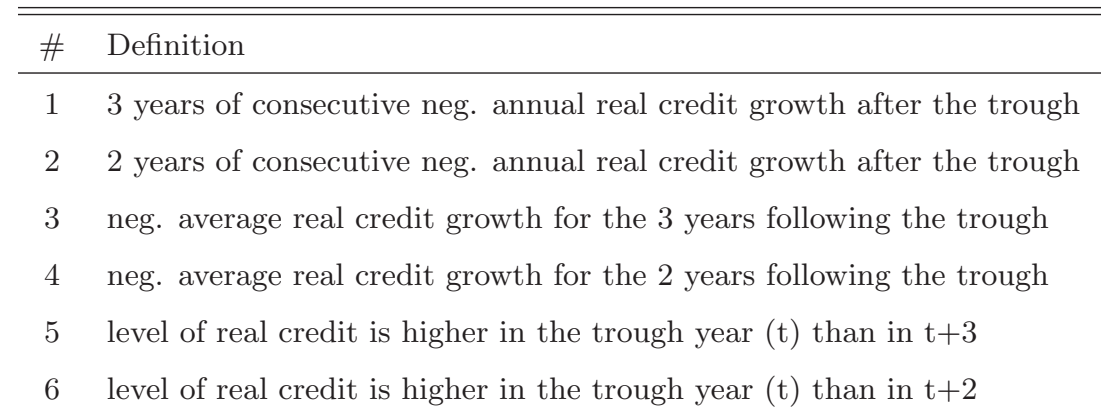

Table 1: Definitions of Credit-less Recoveries

number is 40 and the average is 30 for a total of 2578 observations.

The precise definition of a credit-less recovery inevitably requires some judgement, for example regarding the identification of a recovery in output and how we define "credit-less". Our approach follows the earlier literature in this regard, but we also check the sensitivity of our results for different definitions. Credit-less recoveries are identified in a similar fashion as in Abiad et al. (2011). First, we determine economic downturns based on fluctuations of annual real GDP according to Braun and Larrain (2005). More specifically, troughs are identified as years when cyclical GDP is more than one standard deviation below zero. Cyclical GDP is defined as the difference between the logarithm of real GDP and a trend computed by the Hodrick-Prescott filter ${ }^{1}$. In the case of consecutive troughs we choose the one with the lowest cyclical GDP. Moreover, we do not identify troughs in the first two years of data availability and in the years 2008 and 2009. Then, a recession is dated as starting the year following the previous peak of cyclical GDP and as ending the year of the trough.

Second, we identify credit-less recoveries. More specifically, let us denote the year of the trough as $t$. The onset of a recovery is defined as the period following the trough, i.e., $t+1$. Then, we identify credit-less recoveries according to six different definitions (see Table 1). In the case of definition 1 a recovery is considered to be credit-less if real private credit growth is negative in $t+1, t+2$, and $t+3$ (i.e. in all three years). In the case of definition 2 a recovery is considered to be credit-less if real private credit growth is negative in both $t+1$ and $t+2$. According to definition 3 a recovery is credit-less if the average annual real

\footnotetext{
${ }^{1}$ The smoothing parameter we set to 6.25 as recommended by Ravn and Uhlig (2002) for annual data.
} 
credit growth over the period $t+1$ to $t+3$ is negative. Similarly, in definition 4 a recovery is credit-less if the average annual credit growth over the period $t+1$ to $t+2$ is negative. Finally, in definitions 5 and 6 recovery is said to be credit-less if the real private credit level in $t$ is higher than in $t+3$ and $t+2$, respectively.

\subsection{Some Stylised Facts}

In this subsection, we examine some key features of credit-less recoveries based on descriptive evidence and take a first look at possible determinants of such recoveries. Using the methodology described above we find 211 recoveries in our sample. Table 9 of the Appendix lists the countries and the associated trough years (i.e. the years preceding the onset of the recoveries) for our sample. Table 10 of the Appendix presents the number of identified credit-less recoveries in our sample for the six definitions definitions introduced in the previous subsection. Definition 1, 2, 3, 4, 5, and 6 identify 12, 23, 48, 46, 54, and 50 credit-less recoveries, respectively. Ignoring definition 1 and 2 , which are relatively strict, this implies that more or less every fourth recovery is credit-less. Moreover, the number of credit-less recoveries that we identify in our sample does not vary much across definitions $3,4,5$, and 6. Since definition 5 identifies the highest number of credit-less recoveries and is very similar to definitions used in previous studies we choose it as our preferred definition.

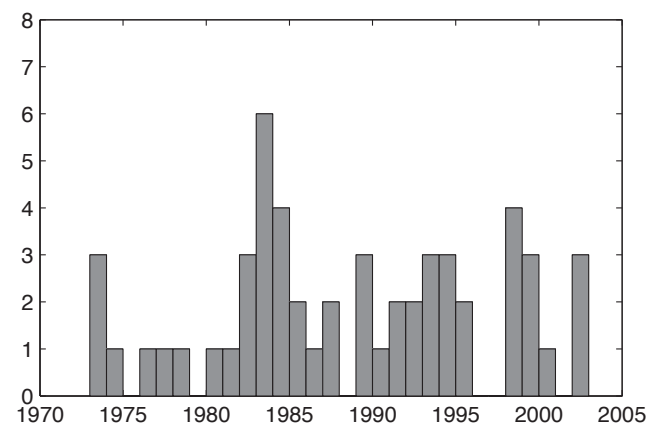

Figure 1: Number of Credit-less Recoveries (Definition 5) Starts per Year.

We find that credit-less recoveries seem to occur almost in every year of the sample, although there is substantial variation over time with peak periods clustered around two or possibly three episodes (see Figure 1). The first and clearest peak in the number of credit-less recoveries took place in the early 1980s following the Latin American debt crisis. 
The second peak, which is somewhat less pronounced, occurred in the first half of the 1990s and was concentrated mainly (but not only) in European countries. Finally, a third peak seems to have occurred in the late 1990s following the Asian crisis.

Knowing that credit-less recoveries have indeed ocurred in the past we wonder whether they are different from "normal" recoveries, i.e., recoveries with credit. Table 2 presents the average real GDP growth among countries during the first three years of "normal" and credit-less recoveries as given by definition 5. Average output growth is 14.2 percent in the first year of a "normal" recovery whereas it less than half (6.4 percent) in the first year of credit-less recoveries. In the following years output growth in credit-less recoveries remains lower than output growth in "normal" recoveries. Output growth during credit-less recoveries thus tends to be weaker than during "normal" recoveries.

\begin{tabular}{lcccc}
\hline \hline & Observations & 1st year & 2nd year & 3rd year \\
\hline "Normal" recoveries & 157 & 14.2 & 5.8 & 6.0 \\
Credit-less recoveries & 54 & 6.4 & 3.9 & 4.1
\end{tabular}

Table 2: Average annual real GDP growth (in \%) during the first three years of recoveries

To gain a first insight into the determinants of credit-less recoveries, we investigate their relation with systemic banking and currency crises. In order to do so, we first identify recessions associated with systemic banking or currency crises. The dates of these crises are obtained from Laeven and Valencia (2008). Recessions are associated with systemic banking or currency crises if the recession starts at least one year after the systemic banking or currency crisis, respectively. Table 9 (in the Appendix) presents the recessions associated with banking crises (trough years are underlined) and to currency crises (trough years in bold) for each country. Moreover, troughs followed by a credit-less recovery according to definition 5 are marked with a star. Looking at Table 3, which summarises this information, we find that every second recession preceded by a banking crisis is followed by a credit-less recovery. Similarly, a bit less than half of the recessions preceded by a currency crisis are followed by a credit-less recovery. The occurrence of a twin crisis, i.e., a systemic banking crisis concurrent with a currency crisis does not increase the frequency of creditless recoveries with respect to banking or currency crises alone. Every second recession preceded by a twin crisis is followed by a credit-less recovery. 


\begin{tabular}{rccr}
\hline \hline Nr. of Recoveries & Banking Crisis & no Banking Crisis & total \\
\hline Credit-less & 15 & 39 & 54 \\
with Credit & 16 & 141 & 157 \\
\hline total & 31 & 180 & 211 \\
\hline \hline Nr. of Recoveries & Currency Crisis & no Currency Crisis & total \\
\hline Credit-less & 14 & 40 & 54 \\
with Credit & 19 & 138 & 157 \\
\hline total & 33 & 178 & 211 \\
\hline \hline Nr. of Recoveries & Twin Crisis & no Twin Crisis & total \\
\hline Credit-less & 9 & 45 & 54 \\
with Credit & 8 & 149 & 157 \\
\hline total & 17 & 194 & 211 \\
\hline
\end{tabular}

Table 3: Credit-less Recoveries, Systemic Banking and Currency Crises.

\section{Determinants of credit-less Recoveries}

\subsection{Empirical Model}

In order to investigate the determinants and the predictability of credit-less recoveries we estimate a panel probit model. The use of a probit model and the construction of a binary credit-less recovery variable are based on our belief that financial crises may have nonlinear effects on output, as they trigger substantial declines in capital flows and lead to balance sheet effects that may result in serious credit constraints. Moreover, this model has been used to study methodologically similar issues such as current account reversals (see Milesi-Ferretti and Razin (1998) and Liesenfeld et al. (2010)), currency crises (see Falcetti and Tudela (2006)), financial crises (see Canova (1994)) or prolonged inflation regimes (see Vansteenkiste (2009)). It should be emphasised that our model is not a tool that can be used to forecast recoveries in output. Instead, our aim is to explain and predict the joint probability of a recovery in output without a pick-up in credit. A recovery in output is defined here as the phase in the cycle that follows a trough as discussed in more detail in Section 2.1. 
Our baseline specification is a static panel probit model, i.e.,

$$
\begin{aligned}
& y_{i t}^{*}=X_{i t}^{\prime} \beta+\epsilon_{i t} \\
& y_{i t}=I\left(y_{i t} *>0\right), \quad i=1, \ldots, N, t=1, \ldots, T
\end{aligned}
$$

where $I\left(y_{i t} *>0\right)$ is an indicator function which transforms the latent variable $y_{i t}^{*}$ into a binary variable $y_{i t}$. The latter variable indicates the onset of a credit-less recovery for country $i$ at time $t$, i.e., $y_{i t}=1$. Therefore, we assume that the dependent variables takes on a value of 1 in the first year of the credit-less recovery. ${ }^{2}$ Moreover, as mentioned in Section 2.1, we use definition 5 as our preferred definition of a credit-less recovery for the regressions. ${ }^{3}$ The vector $x_{i t}$ contains observed regressors which might be driving the occurrence of credit-less recoveries. The selection of regressors and how they enter the model is discussed in the next subsection. The error term $\epsilon_{i t}$ is assumed to be normally distributed with zero mean and fixed variance. The model is estimated using data with annual frequency for data availability reasons. To avoid potential endogeneity issues lagged explanatory variables are used.

First, we estimate a pooled version of the panel probit model assuming that $\epsilon_{i t}$ is independent across time and countries. Since a pooled model is rather restrictive we also use the random effects model proposed by Butler and Moffitt (1982). Introducing random country-specific effects allows us to account for unobserved time invariant heterogeneity across countries. In this model the error term is given by

$$
\epsilon_{i t}=\alpha_{i}+e_{i t}, \quad e_{i t} \sim \operatorname{iidN}(0,1), \alpha_{i} \sim \operatorname{iidN}\left(0, \sigma_{\alpha}^{2}\right) .
$$

The time invariant country-specific effect $\alpha_{i}$ introduces a constant cross-period correlation of $\epsilon_{i t}$ that is given by $\rho=\frac{\sigma_{\alpha}}{\sigma_{\alpha}+1}$.

Within the panel probit framework it is possible to estimate probabilities of onsets of credit-less recoveries conditional on the explanatory variables, i.e.,

$$
\operatorname{Pr}\left(y_{i t}=1 \mid X_{i t}, \hat{\beta}\right)=F\left(X_{i t}^{\prime} \hat{\beta}\right)
$$

where $F$ is the cumulative density function of the standard normal distribution and $\hat{\beta}$ are the estimates obtained from equation (1).

\footnotetext{
${ }^{2}$ We also experimented with setting the dependent variable equal to 1 in the first three years of the credit-less recovery. The results obtained in those regressions remained very similar.

${ }^{3}$ Regression results are robust to different definitions.
} 


\subsection{Explanatory Variables}

The selection of explanatory variables in our model is based on the hypothesis that financial frictions play a key role during a recovery phase following financial crises. A recent example of such a theoretical model is Dagher (2010), where shocks to trend productivity can generate a credit-less recovery in the presence of financial frictions. In this model, a downward revision to trend growth expectations leads to a decline in firms' market value, which, in turn, restricts their capacity to borrow (particularly if firms are overleveraged), but without affecting the de-trended capital level in the economy. Another model that can explain the dichotomy between output and credit following a sudden stop is the one in Calvo et al. (2006b). This model shows that a "liquidity crunch" provoked by a sharp increase in interest rates can lead to a collapse in output and credit, which is followed by a recovery in output as firms restore their liquidity by cutting back on investment. Financial frictions in this model stem from the fact that firms can only obtain short-term financing for working capital (e.g. capital to finance inventory accumulation or international trade), whereas they have to finance physical capital with retained earnings (a typical feature of financial systems in emerging economies).

The explanatory variables that we consider combine elements of the above partial models, while focusing on variables that can signal disruptions in the financial intermediation process or a dependence on international capital flows. More specifically, we consider two types of explanatory variables. First, we include variables that contain information on the recovery in output. Second, we use variables that signal tensions in the financial intermediation process or a high degree of leverage. We use the following explanatory variables.

1. Real GDP growth: This variable captures a "bounce-back" effect, i.e. the deeper the preceding contraction in economic activity the larger the probability is that output will recover (see for example Sichel (1994)). GDP can recover more easily after large contractions in output as unused production capacity remains available. There is thus no need to invest in (and borrow for) new production capacity in order to satisfy a recovery in demand. Moreover, financial accelerator mechanisms suggest that the more severe the downturn, the larger the probability that subsequent credit growth 
may be very weak.

2. Credit-to-GDP ratio: A high (private sector) credit-to-GDP ratio is an indicator of high indebtedness and thus signals that the private sector may have to deleverage (especially after a downturn in GDP). A high credit-to-GDP ratio can also indicate that a credit boom took place (if the ratio increased strongly in the preceding years).

3. Banking crisis dummy: This is our key indicator of financial tensions (taken from Laeven and Valencia (2008)). It typically takes several years after a banking crisis before bank balance sheets have been cleaned up and banks start to provide new credit. In addition, the descriptive analysis in this paper and, among others, in Abiad et al. (2011) suggests that credit-less recoveries are more likely when the downturn is preceded by a banking crisis.

4. Currency crisis dummy: We include this dummy (taken from Laeven and Valencia (2008)) for similar reasons as the banking crisis dummy. International investors may become less willing to invest in countries that experienced a currency crisis in the recent past. This is potentially important for financial intermediation in emerging markets, in particular if there is no developed domestic market for funding (i.e. no deposits). Currency crisis are often associated with sudden stops in capital flows, which, as Calvo et al. (2006a) show, are closely associated with credit-less recoveries.

5. Current account (CA) balance (ratio to GDP): A high current account deficit signals a large dependence on foreign capital inflows, which are typically used to fund the domestic banking system and domestic spending in emerging markets. Moreover, a large CA deficit can be an indicator of an unsustainable credit boom. We therefore expect that the lower the CA balance (or the higher the deficit) is, the higher the likelihood that the following recovery will be credit-less.

6. Investment growth: Inclusion of this variable is based on the model in Calvo et al. (2006b), which suggests that firms cut back on investment to restore their liquidity once financial frictions worsen in the wake of a crisis or sharp downturn.

7. Export growth: This variable may be a key driver of a credit-less recovery if more credit-intensive domestic expenditure components remain depressed. 
As mentioned earlier all explanatory variables are lagged by one year to avoid potential endogeneity problems.

In addition to the above explanatory variables, several other indicators may capture financial constraints or wealth effects and could potentially improve the performance of our models. Such factors include, for example, interest rates, asset prices and various indicators of indebtedness. In addition, fiscal variables could be relevant as problems at the sovereign level can affect the ability to borrow of the private sector and could thus prevent credit from picking up while demand recovers. Finally, variables that capture alternative sources of (external or domestic) financing, such as FDI or trade credit may be useful additional indicators (regarding trade credit, see in particular Coricelli and Roland, 2011). These variables have nevertheless not been included in our empirical models largely due to data constraints. Variables that were available but that are not shown here, such as indicators of indebtedness for the private or public sector, turned out not to be significant.

\section{Empirical Results}

\subsection{Main Results}

First, we estimate a pooled panel probit model ${ }^{4}$. Table 4 summarizes the findings. Column 1 reports the empirical relationship between real GDP growth and the credit-to-GDP ratio, which we expect to be significant determinants based on the definition of credit-less recoveries. As expected, countries with high negative growth are more likely to experience a recovery without credit in the next year. Moreover, a high credit-to-GDP ratio increases the likelihood of a credit-less recovery. In column 2 we add the dummies for currency crises and banking crises. As the descriptive analysis suggested they are both significant determinants of credit-less recoveries. After a recession that was preceded by a currency or banking crisis the recovery is more likely to be credit-less. Column 3 adds the CA balance as an indicator of credit-less recoveries. The higher the CA deficit, i.e., the larger the dependence on foreign capital inflows, the higher the likelihood of a credit-less recovery. Finally, column

\footnotetext{
${ }^{4}$ The number of countries entering the regressions declines to 72 due to lack of data availability of some explanatory variables
} 


\begin{tabular}{lcccc}
\hline \hline Real GDP growth & $-9.49^{* * *}$ & $-8.87^{* * *}$ & $-9.43^{* * *}$ & $-11.24^{* * *}$ \\
Credit/GDP & $0.64^{* * *}$ & $0.56^{* *}$ & $0.56^{* *}$ & $0.67^{* *}$ \\
Currency Crisis & & $1.10^{* * *}$ & $0.87^{* *}$ & $0.90^{* *}$ \\
Banking Crisis & & $1.20^{* * *}$ & $1.37^{* * *}$ & $1.34^{* * *}$ \\
CA/GDP & & $-1.63^{* * *}$ & $-1.69^{* * *}$ \\
Investment growth & & & & $-0.18^{*}$ \\
Export growth & & & & $0.09^{*}$ \\
Constant & $-2.11^{* * *}$ & $-2.24^{* * *}$ & $-2.31^{* * *}$ & $-2.33^{* * *}$ \\
\hline Log likelihood & -176.93 & -149.89 & -127.41 & -116.31 \\
Pseudo $R^{2}$ & 0.24 & 0.36 & 0.39 & 0.43
\end{tabular}

Table 4: Pooled Panel Probit Estimation. * significant at 10\%, ** significant at 5\%, *** significant at $1 \%$.

4 reports results for our preferred regression including two components of the national accounts, namely investment and export growth. The probability of experiencing a credit-less recovery increases in countries with a high negative investment growth and high positive export growth. Our preferred regression also reaches the highest pseudo- $R^{25}$.

In order to control for heterogeneity across panel members, we also estimate a panel probit model using random effects. Table 5 reports the estimation results of this model. All coefficients have the expected sign and are nearly the same as in the pooled probit model. The estimates of the correlation $\rho$ and $\sigma_{\alpha}$ are 0.011 and 0.11 , respectively. The p-value of a likelihood ratio test of the hypothesis, $\rho=0$, is equal to 0.46 implying that we cannot reject the null hypothesis. Therefore, it seems that the panel-level variance component is unimportant and the random effects estimator is not different from the pooled estimator.

\footnotetext{
${ }^{5}$ Since real GDP growth is likely to be correlated with investment growth we run our preferred regression also excluding real GDP growth. Results remain the same except that the psuedo- $R^{2}$ declines, suggesting that the explanatory power of real GDP growth is high.
} 


\begin{tabular}{lcccc}
\hline \hline Real GDP growth & $-9.49^{* * *}$ & $-8.87^{* * *}$ & $-9.43^{* * *}$ & $-11.32^{* * *}$ \\
Credit/GDP & $0.64^{* *}$ & $0.56^{*}$ & $0.56^{*}$ & $0.68^{*}$ \\
Currency Crisis & & $1.10^{* * *}$ & $0.87^{* *}$ & $0.91^{* *}$ \\
Banking Crisis & & $1.20^{* * *}$ & $1.37^{* * *}$ & $1.35^{* * *}$ \\
CA/GDP & & $-1.63^{*}$ & $-1.70^{*}$ \\
Investment growth & & & & -0.18 \\
Export growth & & & & 0.09 \\
Constant & $-2.11^{* * *}$ & $-2.24^{* * *}$ & $-2.32^{* * *}$ & $-2.35^{* * *}$ \\
\hline Log likelihood & -176.93 & -149.89 & -127.42 & -116.30 \\
Pseudo $R^{2}$ & 0.25 & 0.36 & 0.39 & 0.43
\end{tabular}

Table 5: Random Effects Panel Probit Estimation. * significant at 10\%, ** significant at 5\%, *** significant at $1 \%$.

\subsection{Marginal Effects}

The estimated coefficients of the panel probit model do not allow for inference about the quantitative effects of changes in explanatory variables. Therefore, we calculate the marginal effects for specific changes in the regressors. The marginal effects of the covariate $k$ for country $i$ at time $t$ is given by

$$
\left.\frac{\partial F\left(X_{i t}^{\prime} \hat{\beta}\right)}{\partial X_{i t k}}=f\left(X_{i t}^{\prime} \hat{\beta}\right)\right) \hat{\beta}_{k},
$$

where $f$ is the derivative of $F$, i.e., the probability density function of a standard normal distribution. Typically, the marginal effects are calculated at the means of the explanatory variables. Nevertheless, derivative calculation might not be meaningful in the case of dummy variables as regressors. Let $X_{l}$ denote the dummy explanatory variables and $\bar{X}$ the other explanatory variables at their means. Then, the effect of a change in $X_{l}$ on the predicted probabilities of $y$ is calculated as follows.

$$
\operatorname{Pr}\left(y=1 \mid X_{l}=1, \bar{X}, \hat{\beta}\right)-\operatorname{Pr}\left(y=1 \mid X_{l}=0, \bar{X}, \hat{\beta}\right)
$$

Table 6 shows the estimated marginal effects of changes in the explanatory variables for our preferred model (with their standard errors in parenthesis). The size of the marginal effects shows that in particular a preceding decline in output and the occurrence of a banking crisis tend to strongly increase the probability of a credit-less recovery. 


\begin{tabular}{lll}
\hline \hline Real GDP growth & $-0.167^{* * *}(0.038)$ \\
Credit/GDP & $0.009^{* *}(0.005)$ \\
Currency Crisis & $0.042^{* *}(0.039)$ \\
Banking Crisis & $0.101^{* * *}(0.042)$ \\
CA/GDP & $-0.025^{* * *} \quad(0.009)$ \\
Investment growth & $0.001^{*}(0.001)$ \\
Export growth & $-0.003^{*}(0.002)$ \\
\hline
\end{tabular}

Table 6: Marginal effects of changes in explanatory variables.

\section{Predictions}

As described in Section 3.1 it is possible to estimate probabilities of credit-less recoveries for our sample as well as for the years ahead. Therefore, we analyse the accuracy of the estimated model in predicting the onset of credit-less recoveries for specific years and countries. First, we present the estimated probabilities over time for selected countries. Second, we assess the predictive performance of our model using several statistics. Finally, we provide predictions of how likely it is for central and eastern European EU Member States to experience a credit-less recovery in the years ahead. Since the former analysis has shown that there is no difference between a pooled or panel estimator we perform predictions using the pooled model.

First, we present estimated probabilities for the occurrence of credit-less recoveries over time for some selected Latin American, Asian, and central and eastern European countries ${ }^{6}$. Figure 2 in the Appendix shows the predictions over time for Argentina, Brazil, Chile and Colombia. A vertical line denotes the start of a credit-less recovery. For Argentina the two highest peaks (in 1983 and 2003) are associated with estimated probabilities of credit-less recoveries of $70 \%$ and $64 \%$, respectively. Since we indeed identified credit-less recoveries in our earlier descriptive analysis in 1983 and 2002, the model thus predicts their occurrence correctly. However, the estimated probability also peaks in 1996 (although at a lower value), which implies that for the trough of 1995 we may predict a credit-less even though it did not occur. Notably, for the other recoveries in the years 1991 and 1986 the estimated probabilities are relatively low. In the case of Brazil we have two peaks (1984 and 1993) for

\footnotetext{
${ }^{6}$ Figures for all countries in our dataset are available from the authors upon request.
} 
the estimated probabilities that coincide with the actual occurrence of credit-less recoveries. Nevertheless, for 1982 we may predict a false positive. In the case of Chile the predictive performance of the model is very good. For 1984 we predict a credit-less recovery with $80 \%$ probability. For Colombia the model predicts the credit-less recovery starting in 2000 correctly and obtains a very low probability for the (normal) recovery in 1993. Figure 3 in the Appendix presents the estimated probabilities for Hungary, Latvia, Poland and Romania. For Hungary the peak of estimated probabilities in 1992 coincides with the actual occurrence of a credit-less recovery. The predictions for other years are very low. In the case of Latvia we observe estimated probabilities close to zero for the entire period (and there are indeed no credit-less recoveries during the period shown in the chart). For Poland we estimate probabilities around 8\% in 1991 an 1992, with the actual credit-less recovery starting in 1992. Moreover, the model predicts relatively low probabilities over time for Romania for which we have not identified any credit-less recovery. Figure 4 in the Appendix shows predictions for Indonesia, Malaysia, the Philippines and Thailand. For these Asian countries the predictive performance of the model seems very strong. While the predicted probabilities of credit-less recoveries are high when a credit-less recovery actually occurred, the predictions are low when a credit-less recovery did not take place.

Second, we assess the predictive performance of our model using statistics. The accuracy of our model is measured using the Brier Quadratic Probability Score (QPS), the Global Calibration Statistic (GBS), and type I and type II errors. The QPS and GBS statistics are given by $Q P S=\frac{2}{N T} \sum_{i=1}^{N} \sum_{t=1}^{T}\left(P_{i t}-R_{i t}\right)^{2}$ and $G B S=2(\bar{P}-\bar{R})^{2}$, where $P_{i t}$ is the probability forecast of a credit-less recovery and $R_{i t}$ is the actual realization, i.e., the dummy variable taking a value of one at the occurrence of a credit-less recovery. $\bar{P}$ and $\bar{R}$ are their unconditional means. The two statistics range from zero to two with a zero corresponding to perfect accuracy. For our estimated model both statistics are close to zero $(Q P S=0.038$ and $G B S=4.26 * 10^{-6}$ ), implying a good accuracy.

Moreover, we assess the predictive performance of our model by calculating type I errors, i.e., the average conditional probability of a false alarm (a credit-less is predicted although it did not occur), and type II errors, i.e., the average conditional probability of a missing signal (a credit-less recovery is not predicted when it occurred). Evaluating the predictive performance of an estimated binary model using these errors requires the 


\begin{tabular}{l|cccc}
$b$ & $b^{*}=0.027$ & 0.1 & 0.3 & 0.5 \\
\hline type I & 0.1053 & 0.0324 & 0.045 & 0.0044 \\
type II & 0.0455 & 0.4318 & 0.568 & 0.7045
\end{tabular}

Table 7: Behavior of type I and type II errors for different thresholds b

selection of a threshold $b$, whereby a credit-less recovery is predicted if and only if the estimated probability is larger than $b$. Table 7 shows the type I and type II errors for different thresholds. Canova (1994) uses a probability threshold of 50\% whereas Liesenfeld et al. (2010) define the threshold as the argument $b^{*}$ that minimizes the sum of type I and type II errors. Table 7 summarises the behavior of type I and type II errors for different thresholds. For $b^{*}$, the type I and type II errors are very low. The model predicts a creditless recovery when it does not occur only with a probability of $10 \%$. The probability of a missing signal is even lower and equal to $5 \%$. Moreover, the higher the threshold $b$, the lower the probability of a false alarm and the higher the probability of a missing signal. If we, for example, set the threshold to $50 \%$ the probability of a false alarm is only 0.0044 . This implies that it is very likely that the model predicts credit-less recoveries correctly. At the same time, however, the probability of missing a signal is also high for such a high threshold value. In our model, estimated probabilities sometimes peak at a lower level than 0.5 (e.g. Hungary and Brazil). Nevertheless, this may still indicate a high probability of a credit-less recovery if the estimated probabilities for other years are lower.

Since the accuracy of our binary model seems to be adequate, we apply it to provide predictions of how likely it is for central and eastern European EU Member States to experience a credit-less recovery starting in 2010. Table 8 presents the results. Assuming that the trough in output was reached in 2009 the probability of a credit-less recovery in central and eastern European EU Member States during the coming years varies across countries, but is relatively high in the Baltic countries. By contrast, in countries that did not experience a large contraction in economic activity or less financial stress the probability of a recovery without credit seems substantially lower. 


\begin{tabular}{lr}
\hline \hline Bulgaria & $14 \%$ \\
Czech Republic & $7 \%$ \\
Estonia & $43 \%$ \\
Hungary & $15 \%$ \\
Latvia & $94 \%$ \\
Lithuania & $41 \%$ \\
Poland & $1 \%$ \\
Romania & $13 \%$
\end{tabular}

Table 8: Estimated predictions of credit-less recoveries for central and eastern European EU Member States.

\section{Conclusion}

This paper focuses on the characteristics and particularly the determinants of credit-less recoveries. After building a dataset and documenting some stylised facts of credit-less recoveries in emerging market economies, we use panel probit models to analyse key determinants of credit-less recoveries. We also apply our preferred model to predict the probability of credit-less recoveries in central and eastern European EU Member States in the coming years.

Our main findings are the following. First, our frequency analysis confirms earlier findings that credit-less recoveries are not at all rare events. In our sample of low and middle income economies one out of four recoveries in output occurs without a pick-up in credit. Moreover, our analysis shows that the frequency of credit-less recoveries doubles after a banking or currency crisis. Second, panel probit models suggest that credit-less recoveries are typically preceded by large declines in economic activity and financial stress, in particular if private sector indebtedness is high and the country is reliant on foreign capital inflows. This suggests that financial frictions may indeed play a key role in the stagnation of credit despite that output recovers. Third and finally, our models show that (assuming that the trough in output was reached in 2009) the probability of a credit-less recovery in central and eastern European EU Member States during the coming years varies across countries, but is relatively high in the Baltic States.

Our findings have the following implications. They suggest that a recovery in output 
following a recession associated with financial stress may not be accompanied by a pick-up in lending. New credit may thus not be a necessary condition for output to recover. This does not mean, however, that credit is irrelevant for a recovery in output. Credit-less recoveries tend to be relatively weak and other related research (e.g. Kannan (2010)) shows that stressed credit conditions contribute to the sluggishness of these recoveries. To the extent that bottlenecks in the supply of credit play a role, policy measures aimed at supporting the financial intermediation process may help the recovery in output. Such policy measures should not only focus on the financial sector, but also concentrate on restoring confidence among lenders and savers. A credible fiscal consolidation strategy and structural reforms aimed at correcting the root causes of the macroeconomic imbalances built up in previous years should play a key role in this regard. Even more important are pre-emptive policies aimed at avoiding the build-up of macroeconomic imbalances. 


\section{References}

Abiad, A., Dell'Ariccia, G. and Li, B. (2011). Creditless recoveries, Working Paper 11/58, IMF.

Biggs, M., Mayer, T. and Pick, A. (2009). Credit and economic recovery, Working Paper 218, DNB.

Braun, M. and Larrain, B. (2005). Finance and the business cycle: International interindustry evidence, Journal of Finance 15(3): 1097-1128.

Brown, M.and Ongena, S., Popov, A. and Yesin, P. (2010). Who needs credit and who gets credit in eastern europe?, Working Paper 2010-9, Swiss National Bank.

Butler, J. S. and Moffitt, R. (1982). A computationally efficient quadrature procedure for the one-factor multinomial probit model, Econometrica 50: 761-764.

Calvo, G. A., Izquierdo, A. and Talvi, E. (2006a). The economics of sudden stops in emerging economies, American Economic Review 96(2): 405-410.

Calvo, G. A., Izquierdo, A. and Talvi, E. (2006b). Phoenix miracles in emerging markets: Recovering without credit from systemic banking crises, Working Paper 570, InterAmerican Development Bank.

Canova, F. (1994). Were financial crises predictable?, Journal of Money, Credit and Banking 26(1): 102-124.

Cerra, V. and Saxena, S. W. (2008). Growth dynamics: The myth of economic recovery, American Economic Review 98(1): 439-57.

Coricelli, F. and Roland, I. (2011). How do credit conditions shape economic recoveries?, Discussion Paper 8325, CEPR.

Dagher, J. C. (2010). Sudden stops, output collapses, and credit collapses, Working Paper 10/176, IMF.

Falcetti, E. and Tudela, M. (2006). Modelling currency crises in emerging markets: A dynamic probit model with unobserved heterogeneity and autocorrelated errors, Oxford Bulletin of Economics and Statistics 68: 445-471. 
Kannan, P. (2010). Credit conditions and recoveries from recessions associated with financial crises, Working Paper 10/83, IMF.

Laeven, L. A. and Valencia, F. (2008). Systemic banking crises: A new database, Working Paper 08/224, IMF.

Liesenfeld, R., Moura, G. V. and Richard, J. F. (2010). Determinants and dynamics of current account reversals: An empirical analysis, Oxford Bulletin of Economics and Statistics 72(4): $486-517$.

Milesi-Ferretti, G. M. and Razin, A. (1998). Sharp reductions in current account deficits: An empirical analysis, European Economic Review 42: 897-908.

Ravn, M. O. and Uhlig, H. (2002). On adjusting the hodrick-prescott filter for the frequency of observations, Review of Economics and Statistics 84(2): 371-376.

Sichel, D. E. (1994). Inventories and the three phases of the business cycle, Journal of Business and Economic Statistics 12(3): 269-277.

Vansteenkiste, I. (2009). What triggers prolonged inflation regimes, Working Paper 1109, European Central Bank. 

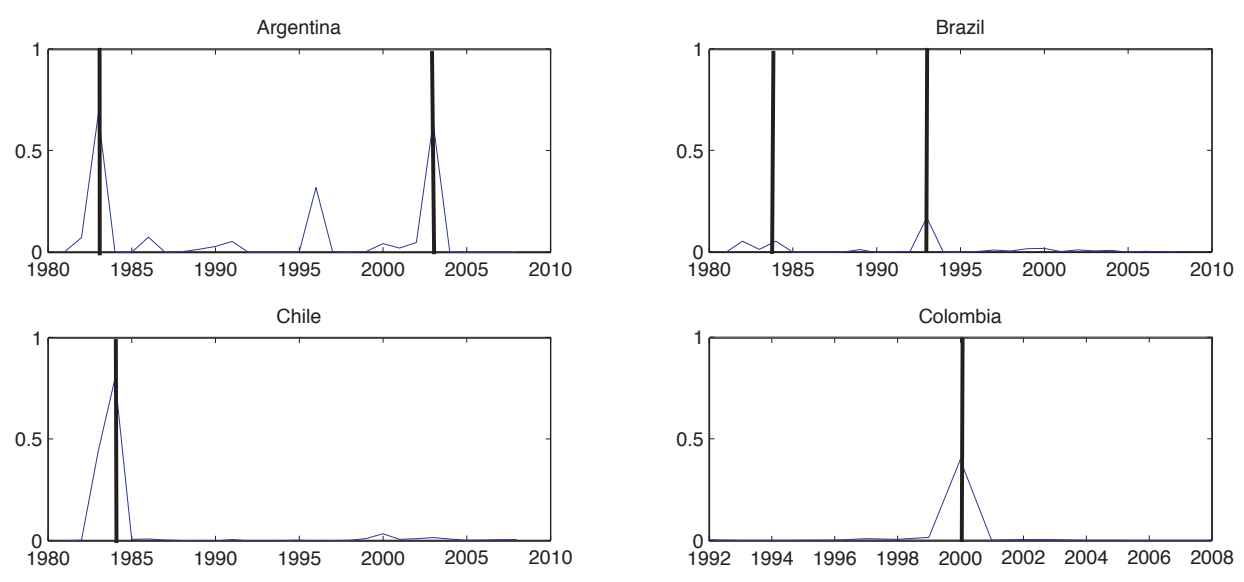

Figure 2: Estimated probabilities of credit-less recoveries over time for Argentina, Brazil, Chile and Colombia.
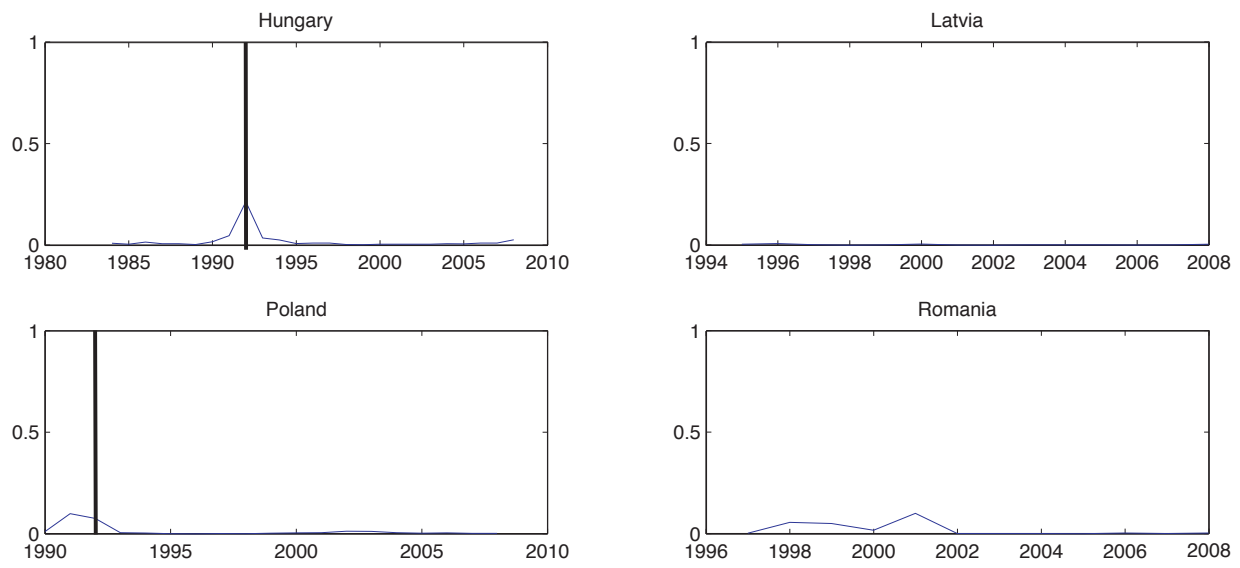

Figure 3: Estimated probabilities of credit-less recoveries over time for Hungary, Latvia, Poland and Romania.
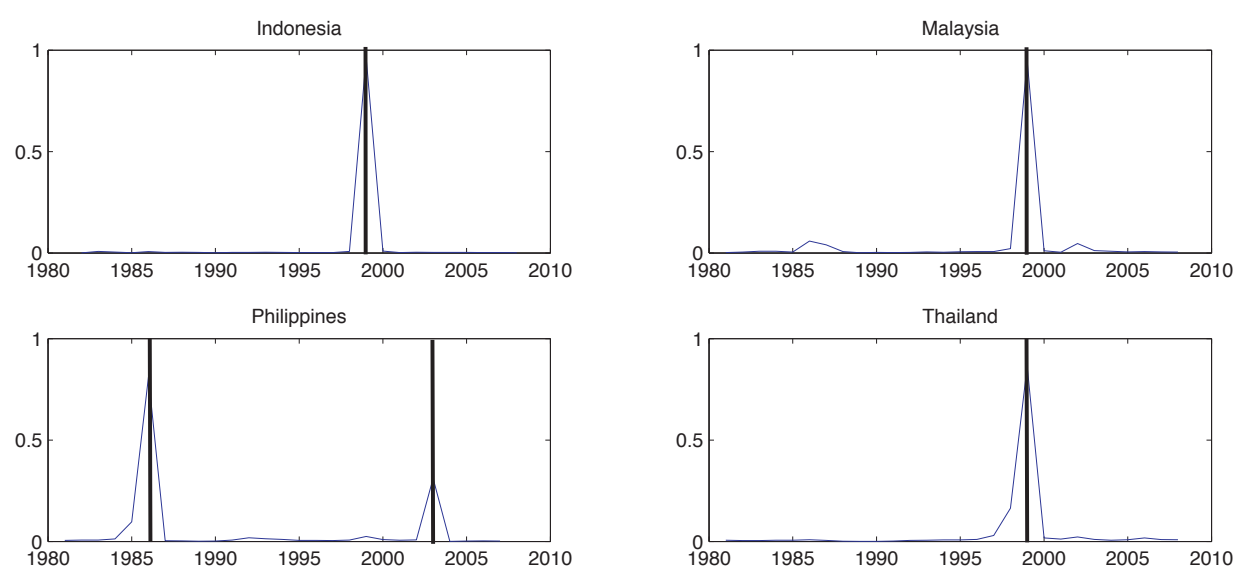

Figure 4: Estimated probabilities of credit-less recoveries over time for Indonesia, Malaysia, Philippines and Thailand. 


\begin{tabular}{|c|c|c|c|c|c|c|c|}
\hline Id & Country & Trough & Years & & & & total \\
\hline 1 & Albania & 1992 & & & & & 1 \\
\hline 2 & Argentina & $\underline{1982}^{*}$ & 1985 & 1990 & $\underline{1995}$ & $\underline{2002}^{*}$ & 5 \\
\hline 3 & Bangladesh & 1975 & 1980 & $\underline{1989}$ & & & 3 \\
\hline 4 & Barbados & $1973^{*}$ & 1983 & 1992 & & & 3 \\
\hline 5 & Belarus & 1995 & & & & & 1 \\
\hline 6 & Belize & 1982 & 1986 & 1998 & & & 3 \\
\hline 7 & Benin & 1974 & 1979 & 1983 & $\underline{1989 *}$ & & 4 \\
\hline 8 & Bolivia & 1974 & $1983^{*}$ & 1986 & & & 3 \\
\hline 9 & Botswana & 1975 & $1977^{*}$ & 1987 & 1996 & & 4 \\
\hline 10 & Brazil & $1983^{*}$ & $\underline{1992}^{*}$ & & & & 2 \\
\hline 11 & Bulgaria & & & & & & 0 \\
\hline 12 & Burkina Faso & $1984^{*}$ & $1989^{*}$ & 1998 & & & 3 \\
\hline 13 & Burundi & $1972^{*}$ & 1975 & 1979 & 1984 & $\underline{1996}$ & 5 \\
\hline 14 & Cambodia & 1990 & 1998 & 2003 & & & 3 \\
\hline 15 & Cameroon & $1993^{*}$ & & & & & 1 \\
\hline 16 & Chile & 1975 & $\underline{1983}^{*}$ & & & & 2 \\
\hline 17 & Colombia & 1977 & $1985^{*}$ & 1992 & $\underline{1999^{*}}$ & & 4 \\
\hline 18 & Congo, Republic of & 1978 & $1986^{*}$ & & & & 2 \\
\hline 19 & Costa Rica & 1976 & 1982 & 1991 & $\underline{1996}$ & & 4 \\
\hline 20 & Croatia & $\underline{1998}$ & & & & & 1 \\
\hline 21 & Czech Republic & & & & & & 0 \\
\hline 22 & Dominica & 1979 & 2002 & & & & 2 \\
\hline 23 & Dominican Republic & 1985 & 1991 & $\underline{2004}$ & & & 3 \\
\hline 24 & Ecuador & $\underline{1983}$ & $1987^{*}$ & $\underline{1999}^{*}$ & & & 3 \\
\hline 25 & Egypt & 1986 & & & & & 1 \\
\hline 26 & El Salvador & $1989^{*}$ & & & & & 1 \\
\hline 27 & Equatorial Guinea & 1993 & & & & & 1 \\
\hline 28 & Estonia & 1995 & 1999 & & & & 2 \\
\hline 29 & Fiji & 1983 & 1988 & 1991 & & & 3 \\
\hline 30 & Georgia & 2002 & & & & & 1 \\
\hline 31 & Grenada & 1996 & 2001 & 2004 & & & 3 \\
\hline 32 & Guatemala & 1975 & $1983^{*}$ & 1986 & 2005 & & 4 \\
\hline 33 & Guinea-Bissau & $1998^{*}$ & 2003 & & & & 2 \\
\hline 34 & Honduras & 1975 & 1983 & $1999^{*}$ & & & 3 \\
\hline 35 & Hungary & 1985 & $1991^{*}$ & & & & 2 \\
\hline 36 & India & 1974 & 1979 & 2002 & & & 3 \\
\hline 37 & Indonesia & $\underline{1998}^{*}$ & & & & & 1 \\
\hline 38 & Iran, I.R. of & $1980^{*}$ & 1988 & & & & 2 \\
\hline 39 & Israel & 1972 & 1977 & & & & 2 \\
\hline 40 & Jamaica & $1976^{*}$ & 1980 & 1986 & & & 3 \\
\hline 41 & Jordan & 1985 & $\underline{1991}$ & & & & 2 \\
\hline 42 & Kazakhstan & 1998 & & & & & 1 \\
\hline 43 & Kenya & 1976 & 1978 & 1984 & & & 3 \\
\hline
\end{tabular}




\begin{tabular}{|c|c|c|c|c|c|c|c|c|}
\hline Id & Country & Trough & Years & & & & & total \\
\hline 44 & Korea, Republic of & 1980 & $\underline{1998}$ & & & & & 2 \\
\hline 45 & Kuwait & 1975 & 1982 & 1988 & 1992 & & & 4 \\
\hline 46 & Latvia & 1993* & & & & & & 1 \\
\hline 47 & Lesotho & 1986 & & & & & & 1 \\
\hline 48 & Lithuania & & & & & & & 0 \\
\hline 49 & Macedonia, FYR & 2002 & & & & & & 1 \\
\hline 50 & Madagascar & 1978 & $1982^{*}$ & 2002 & & & & 3 \\
\hline 51 & Malawi & $1990^{*}$ & $1994^{*}$ & 2001 & & & & 3 \\
\hline 52 & Malaysia & 1975 & 1986 & $\underline{1998} *$ & & & & 3 \\
\hline 53 & Malta & $1974^{*}$ & 1987 & 1994 & 2004 & & & 4 \\
\hline 54 & Mauritius & 1975 & 1980 & 1984 & & & & 3 \\
\hline 55 & Mexico & 1977 & 1983 & 1988 & $\underline{1995}^{*}$ & & & 4 \\
\hline 56 & Mongolia & 1985 & 1993 & 2002 & & & & 3 \\
\hline 57 & Morocco & 1973 & 1975 & 1981 & 1987 & 1993 & 1995 & 6 \\
\hline 58 & Nicaragua & $\underline{1993} *$ & $\underline{2003}$ & & & & & 2 \\
\hline 59 & Niger & $1992^{*}$ & 2000 & & & & & 2 \\
\hline 60 & Nigeria & 1972 & & & & & & 1 \\
\hline 61 & Oman & 1980 & 1987 & & & & & 2 \\
\hline 62 & Pakistan & $1972^{*}$ & 1977 & 1979 & 2003 & & & 4 \\
\hline 63 & Panama & 1976 & 1988 & & & & & 2 \\
\hline 64 & Paraguay & 1976 & $1983^{*}$ & 1986 & $2000^{*}$ & & & 4 \\
\hline 65 & Peru & 1978 & $1983^{*}$ & 1990 & 1992 & & & 4 \\
\hline 66 & Philippines & $\underline{1985}^{*}$ & $\underline{2002}^{*}$ & & & & & 2 \\
\hline 67 & Poland & $1982^{*}$ & $1991 *$ & & & & & 2 \\
\hline 68 & Romania & $\underline{1992}$ & 2000 & & & & & 2 \\
\hline 69 & Russian Federation & 1994 & $\underline{1998}$ & & & & & 2 \\
\hline 70 & Saudi Arabia & 1978 & 1983 & $1987^{*}$ & 2002 & & & 4 \\
\hline 71 & Senegal & 1973 & $1978^{*}$ & $1981 *$ & $1984^{*}$ & 2002 & & 5 \\
\hline 72 & Slovak Republic & & & & & & & 0 \\
\hline 73 & Slovenia & 1992 & & & & & & 1 \\
\hline 74 & Sri Lanka & 1977 & 1982 & 1996 & 2002 & & & 4 \\
\hline 75 & Swaziland & 1986 & 1990 & & & & & 2 \\
\hline 76 & Syrian Arab Republic & 1973 & 1979 & 1989 & & & & 3 \\
\hline 77 & Tanzania & & & & & & & 0 \\
\hline 78 & Thailand & 1975 & 1986 & $\underline{1998}^{*}$ & & & & 3 \\
\hline 79 & Togo & 1979 & 1983 & $1993^{*}$ & & & & 3 \\
\hline 80 & Trinidad and Tobago & 1975 & $1984^{*}$ & 2002 & & & & 3 \\
\hline 81 & Tunisia & 1982 & 1986 & 1989 & 1995 & & & 4 \\
\hline 82 & Turkey & 1989 & 1994 & $\underline{2001}$ & & & & 3 \\
\hline 83 & Ukraine & $1994^{*}$ & & & & & & 1 \\
\hline 84 & Uruguay & $\underline{1984}^{*}$ & $2002^{*}$ & & & & & 2 \\
\hline 85 & Vietnam & $\underline{1999}$ & & & & & & 1 \\
\hline \multirow[t]{2}{*}{86} & Zambia & 1979 & 1992 & $1995^{*}$ & & & & 3 \\
\hline & total & & & & & & & 211 \\
\hline
\end{tabular}

Table 9: Trough Years. $A^{*}$ denotes a trough which is followed by a credit-less recovery (definition 5). Underlined and bold trough years refer to recessions associated with systematic banking crises and currency crises, respectively. 


\begin{tabular}{|c|c|c|c|c|c|c|c|c|}
\hline Year & Country & Id & Def. 1 & Def. 2 & Def. 3 & Def. 4 & Def. 5 & Def. \\
\hline 1973 & Burundi & 13 & & & & & $\mathrm{x}$ & \\
\hline 1973 & Pakistan & 62 & $\mathrm{x}$ & $\mathrm{x}$ & $\mathrm{x}$ & $\mathrm{x}$ & $\mathrm{x}$ & $\mathrm{x}$ \\
\hline 1974 & Barbados & 4 & & $\mathrm{x}$ & $\mathrm{x}$ & $\mathrm{x}$ & $\mathrm{x}$ & $\mathrm{x}$ \\
\hline 1974 & Syrian Arab Republic & 76 & & & & $\mathrm{x}$ & & $\mathrm{x}$ \\
\hline 1975 & Malta & 53 & & & $\mathrm{x}$ & $\mathrm{x}$ & $\mathrm{x}$ & $\mathrm{x}$ \\
\hline 1977 & Jamaica & 40 & $\mathrm{x}$ & $\mathrm{x}$ & $\mathrm{x}$ & $\mathrm{x}$ & $\mathrm{x}$ & $\mathrm{x}$ \\
\hline 1978 & Botswana & 9 & & & $\mathrm{x}$ & & $\mathrm{x}$ & \\
\hline 1979 & Congo & 18 & & & & $\mathrm{x}$ & & $\mathrm{x}$ \\
\hline 1979 & Senegal & 71 & & & $\mathrm{x}$ & $\mathrm{x}$ & $\mathrm{x}$ & $\mathrm{x}$ \\
\hline 1981 & Iran & 38 & & $\mathrm{x}$ & $\mathrm{x}$ & $\mathrm{x}$ & $\mathrm{x}$ & $\mathrm{x}$ \\
\hline 1982 & Senegal & 71 & & & $\mathrm{x}$ & & $\mathrm{x}$ & \\
\hline 1983 & Argentina & 2 & $\mathrm{x}$ & $\mathrm{x}$ & $\mathrm{x}$ & $\mathrm{x}$ & $\mathrm{x}$ & $\mathrm{x}$ \\
\hline 1983 & Madagascar & 50 & & $\mathrm{x}$ & $\mathrm{x}$ & $\mathrm{x}$ & $\mathrm{x}$ & $\mathrm{x}$ \\
\hline 1983 & Poland & 67 & & $\mathrm{x}$ & $\mathrm{x}$ & $\mathrm{x}$ & $\mathrm{x}$ & $\mathrm{x}$ \\
\hline 1984 & Barbados & 4 & & & & $\mathrm{x}$ & & $\mathrm{x}$ \\
\hline 1984 & Bolivia & 8 & & & $\mathrm{x}$ & & $\mathrm{x}$ & $\mathrm{x}$ \\
\hline 1984 & Brazil & 10 & & & $\mathrm{x}$ & & $\mathrm{x}$ & \\
\hline 1984 & Chile & 16 & & & $\mathrm{x}$ & & $\mathrm{x}$ & \\
\hline 1984 & Ecuador & 24 & & & & $\mathrm{x}$ & & $\mathrm{x}$ \\
\hline 1984 & Guatemala & 32 & & & $\mathrm{x}$ & $\mathrm{x}$ & $\mathrm{x}$ & $\mathrm{x}$ \\
\hline 1984 & Paraguay & 64 & & $\mathrm{x}$ & $\mathrm{x}$ & $\mathrm{x}$ & $\mathrm{x}$ & $\mathrm{x}$ \\
\hline 1984 & Peru & 65 & $\mathrm{x}$ & $\mathrm{x}$ & $\mathrm{x}$ & $\mathrm{x}$ & $\mathrm{x}$ & $\mathrm{x}$ \\
\hline 1985 & Burkina Faso & 12 & & & $\mathrm{x}$ & $\mathrm{x}$ & $\mathrm{x}$ & $\mathrm{x}$ \\
\hline 1985 & Senegal & 71 & & $\mathrm{x}$ & $\mathrm{x}$ & $\mathrm{x}$ & $\mathrm{x}$ & $\mathrm{x}$ \\
\hline 1985 & Trinidad and Tobago & 80 & & & $\mathrm{x}$ & $\mathrm{x}$ & $\mathrm{x}$ & $\mathrm{x}$ \\
\hline 1985 & Uruguay & 84 & & & $\mathrm{x}$ & & $\mathrm{x}$ & \\
\hline 1986 & Colombia & 17 & & & & & $\mathrm{x}$ & $\mathrm{x}$ \\
\hline 1986 & Phillippines & 66 & & & $\mathrm{x}$ & $\mathrm{x}$ & $\mathrm{x}$ & $\mathrm{x}$ \\
\hline 1987 & Congo & 18 & $\mathrm{x}$ & $\mathrm{x}$ & $\mathrm{x}$ & $\mathrm{x}$ & $\mathrm{x}$ & $\mathrm{x}$ \\
\hline 1987 & Malaysia & 52 & & & & $\mathrm{x}$ & & $\mathrm{x}$ \\
\hline 1987 & Mexico & 55 & & & & $\mathrm{x}$ & & $\mathrm{x}$ \\
\hline 1988 & Ecuador & 24 & & $\mathrm{x}$ & $\mathrm{x}$ & $\mathrm{x}$ & $\mathrm{x}$ & $\mathrm{x}$ \\
\hline 1988 & Saudi Arabia & 70 & & & & & $\mathrm{x}$ & \\
\hline 1989 & Panama & 63 & & & & $\mathrm{x}$ & & $\mathrm{x}$ \\
\hline 1990 & Benin & 7 & $\mathrm{x}$ & $\mathrm{x}$ & $\mathrm{x}$ & $\mathrm{x}$ & $\mathrm{x}$ & $\mathrm{x}$ \\
\hline 1990 & Burkina Faso & 12 & & & $\mathrm{x}$ & $\mathrm{x}$ & $\mathrm{x}$ & $\mathrm{x}$ \\
\hline 1990 & El Salvador & 26 & & & $\mathrm{x}$ & $\mathrm{x}$ & $\mathrm{x}$ & $\mathrm{x}$ \\
\hline 1991 & Malawi & 51 & & & $\mathrm{x}$ & $\mathrm{x}$ & $\mathrm{x}$ & \\
\hline 1992 & Hungary & 35 & $\mathrm{x}$ & $\mathrm{x}$ & $\mathrm{x}$ & $\mathrm{x}$ & $\mathrm{x}$ & $\mathrm{x}$ \\
\hline 1992 & Poland & 67 & & & $\mathrm{x}$ & $\mathrm{x}$ & $\mathrm{x}$ & $\mathrm{x}$ \\
\hline 1993 & Brazil & 10 & & & $\mathrm{x}$ & & $\mathrm{x}$ & $\mathrm{x}$ \\
\hline 1993 & Niger & 59 & $\mathrm{x}$ & $\mathrm{x}$ & $\mathrm{x}$ & $\mathrm{x}$ & $\mathrm{x}$ & $\mathrm{x}$ \\
\hline 1994 & Cameroon & 15 & & $\mathrm{x}$ & $\mathrm{x}$ & $\mathrm{x}$ & $\mathrm{x}$ & $\mathrm{x}$ \\
\hline 1994 & Latvia & 46 & & & $\mathrm{x}$ & $\mathrm{x}$ & $\mathrm{x}$ & $\mathrm{x}$ \\
\hline 1994 & Nicaragua & 58 & & & $\mathrm{x}$ & $\mathrm{x}$ & $\mathrm{x}$ & $\mathrm{x}$ \\
\hline 1994 & Togo & 79 & & $\mathrm{x}$ & $\mathrm{x}$ & $\mathrm{x}$ & $\mathrm{x}$ & $\mathrm{x}$ \\
\hline 1995 & Malawi & 51 & $\mathrm{x}$ & $\mathrm{x}$ & $\mathrm{x}$ & $\mathrm{x}$ & $\mathrm{x}$ & $\mathrm{x}$ \\
\hline 1995 & Ukraine & 83 & & $\mathrm{x}$ & $\mathrm{x}$ & $\mathrm{x}$ & $\mathrm{x}$ & $\mathrm{x}$ \\
\hline 1996 & Mexico & 55 & & & & & $\mathrm{x}$ & $\mathrm{x}$ \\
\hline 1996 & Zambia & 86 & & & $\mathrm{x}$ & & $\mathrm{x}$ & \\
\hline 1999 & Guinea-Bissau & 33 & & & $\mathrm{x}$ & & $\mathrm{x}$ & \\
\hline 1999 & Indonesia & 37 & $\mathrm{x}$ & $\mathrm{x}$ & $\mathrm{x}$ & $\mathrm{x}$ & $\mathrm{x}$ & $\mathrm{x}$ \\
\hline 1999 & Malaysia & 52 & & $\mathrm{x}$ & $\mathrm{x}$ & $\mathrm{x}$ & $\mathrm{x}$ & $\mathrm{x}$ \\
\hline 1999 & Thailand & 78 & $\mathrm{x}$ & $\mathrm{x}$ & $\mathrm{x}$ & $\mathrm{x}$ & $\mathrm{x}$ & $\mathrm{x}$ \\
\hline 2000 & Colombia & 17 & & & $\mathrm{x}$ & $\mathrm{x}$ & $\mathrm{x}$ & $\mathrm{x}$ \\
\hline 2000 & Ecuador & 24 & & & $\mathrm{x}$ & & $\mathrm{x}$ & \\
\hline 2000 & Honduras & 34 & & & $\mathrm{x}$ & $\mathrm{x}$ & $\mathrm{x}$ & $\mathrm{x}$ \\
\hline 2001 & Paraguay & 64 & & & $\mathrm{x}$ & $\mathrm{x}$ & $\mathrm{x}$ & $\mathrm{x}$ \\
\hline 2002 & Malawi & 51 & & & & & & $\mathrm{x}$ \\
\hline 2003 & Argentina & 2 & & & & $\mathrm{x}$ & $\mathrm{x}$ & $\mathrm{x}$ \\
\hline 2003 & Phillippines & 66 & & & & & $\mathrm{x}$ & \\
\hline \multirow[t]{3}{*}{2003} & Uruguay & 84 & $\mathrm{x}$ & $\mathrm{x}$ & $\mathrm{x}$ & $\mathrm{x}$ & $\mathrm{x}$ & $\mathrm{x}$ \\
\hline & total & & 12 & 23 & 48 & 46 & 54 & 50 \\
\hline & Relative Frequency & & 0.06 & 0.11 & 0.23 & 0.22 & 0.26 & 0.24 \\
\hline
\end{tabular}

Table 10: Credit-less recoveries according to different definitions (starting year in first column). 
